\title{
Gustav Adolf Deissmann (1866-1937) and the revival of archaeological excavations at Ephesus after the First World War*
}

\begin{abstract}
In his lifetime Gustav Adolf Deissmann ${ }^{1}$ was celebrated as the reviver of the archaeological excavations of Ephesus and the one man through whose ‘unceasing benefaction' the city's historical heritage was able to be preserved for future generations. Yet his unique and long protracted rescuing role for the once-foremost city in Asia has today been almost completely forgotten; and even among archaeologists and historians few would associate his name with archaeology, fewer still with the salvaging of Ephesus' extraordinary story. Nevertheless, immeasurable historical losses were averted in the nick of time because of Deissmann's proactive determination to preserve the legacy of Ephesus's past millennia, at a historical moment when much of it was about to pass into oblivion.
\end{abstract}

The son of a German Lutheran Pastor, Adolf Deissmann was born on 7 November 1866 in Langenscheid (Hessen), educated at Tübingen, Berlin, Herborn and Marburg, and later held the chair of New Testament Theology at Heidelberg (1897-1908) and Berlin (1908-1935). He is best known for his pioneering work in New Testament Philology, set out in his first three books, which he regarded as an interlinked trilogy: »Bibelstudien« (1895), »Neue Bibelstudien« (1897) and »Licht vom Osten« (1908).

In contrast, his unique role in the post-First World War revival of archaeological excavations at Ephesus has been all but forgotten. So forgotten, in fact, that a reasonably recognisable picture of Deissmann (in a full-page photograph) published in the impressive book »Ephesus. 100 years of Austrian Research «, has not only gone unrecognised by its authors, but was also placed within the wrong era $-1895-1913^{2}$ ! The work also fails to give any credit to Deissmann, even though on 15 July 1930 the Institute had bestowed on him full membership in gratitude of his extraordinary labours.

The purpose of this short article is to raise awareness of Deissmann's seminal contribution to the archaeological reclamation and restoration of Ephesus.

On his birthday in 1926 Deissmann wrote in his diary: »Ephesus ... früh zum Prätorium + Stadion ... erhielt ein Diplom« (»Ephesus ... early to the Praetorium and Stadium ... received a diploma«). Unfortunately, the original of this unique diploma survives today only in the form of a single phtograph held at the Austrian Archaeological Institute (ÖAI) at Vienna. It consists of a hand painted seven-piece collage, with a centrally mounted photograph of the five-member excavation team ${ }^{3}$, but although this is not the place to discuss it at length, some relevant observations are in order (fig. 1).

The central panel of the diploma shows from left to right: Franz Miltner (1901-1959), Adolf Deissmann, Josef Keil (1878-1963), Ahmet Aziz Oğan (1888-1956), Max Theuer (1878-1949). The uppermost image clearly depicts a westward view from the theatre (extending past the Arkadiane), with the silted harbour and

* I gratefully acknowledge my indebtedness to Dr. Gerhard Deissmann (Bremen) for entrusting me with free access to his father's personal diary; to Dr. Manfred Kandler (Vienna) for granting permission to make use of the diploma photograph, and to Prof. Greg Horsley (Armidale) for his many helpful suggestions.

${ }^{1}$ Since Deissmann himself spelt his name variously with either ' $\beta$ ' or 'ss', I shall use the Anglo-Saxon double sibilant, except when citations demand otherwise.

${ }^{2}$ G. Wiplinger - G. Wlach, Ephesus. 100 Years of Austrian Research (1996) 35 fig. 42. Deissmann standing at front left.

${ }^{3}$ In an e-mail (20. 3. 2006) Dr. M. Kandler has kindly provided me with strong evidence that suggests the artwork to be that of the team member Max Theuer. 
the Pagos Astyagu (left) on the western tip of Bülbül Dağ. The telltale protrusion (top left) shows the Hellenic watchtower (or lighthouse?), traditionally also known as 'Paul's prison', and forms part of the city wall's extreme west. In 1906 Deissmann gained one of his first unforgettable impressions from here, of Ephesus' vast expanse and archaeological wealth ${ }^{4}$. The modern inscription in ancient Greek on the left, almost certainly drafted by Josef Keil, celebrates Deissmann's $60^{\text {th }}$ birthday and the lasting benefit he has brought to Ephesus.

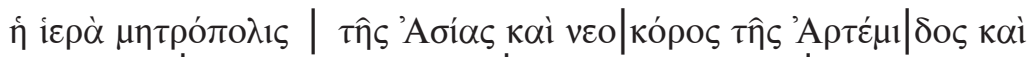

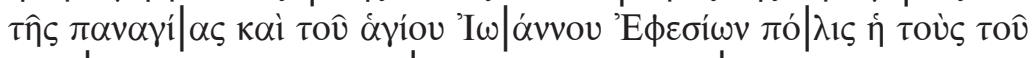

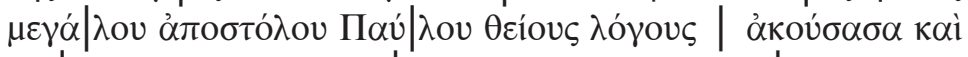

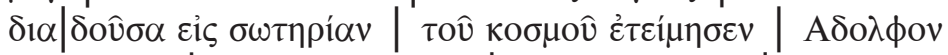

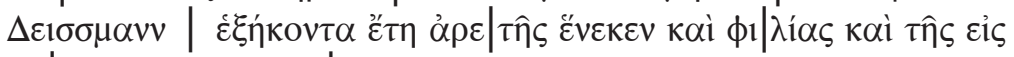

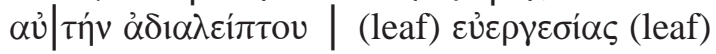

»The holy metropolis of Asia and temple-warden of Artemis and of the All-Holy One (Mary) and of Saint John, the city of the Ephesians, after hearing the divine words of the great Apostle Paul, and disseminating them for the salvation of the world, honoured Adolf Deissmann on his sixty years, for his excellence and friendship and ceaseless benefaction towards it.«

On the bottom left is a published votive relief of Cybele standing with two lions between Zeus and Hermes ${ }^{5}$. Deissmann briefly discussed this relief in a published article ${ }^{6}$, although there he identified the figure on the left as Attis. An entry in his diary (27. 10. 1926) simply states »Ephesus; Heiligtum des Zeus + der Kybele; 6 Reliefs«, but since this particular relief was reproduced on his diploma, it appears to suggest his likely involvement in its discovery. This proposition is reinforced in J. Keil's report ${ }^{7}$. Here he discusses similar votive reliefs and includes a comparable photo to the one on the diploma, but mentions that two had been discovered in the town of Selçuk during the 1926 season $^{8}$, which clearly alludes to Deissmann's work there (see below).

The plate on the right portrays a griffin clasping an animal (young lion?) in its clutches. I owe the identification $^{9}$ of this relief to Dr. M. Kandler, who has therewith confirmed my suspicion that it represents a second re-discovery by Deissmann. For similar to the Cybele relief this image also depicts a relief plate originally unearthed by Georgios A. Sotiriou (see below) and later spirited away for the reconstruction of Selçuk.

In between these two reliefs is a second painting, this one of the Byzantine citadel on the Ayasoluk hill, northeast of Ephesus and seen from the less commonly represented south. The ruins of the St. John's basilica had only been partially excavated by then (see below), but are shown in the foreground; the various houses belong to the northerly outskirts of the then newly built town of Selçuk.

All these border designs, including the honorific inscription in Greek, are part of the aesthetic intent of the diploma. It is the German text on the right that is particularly informative, however, for it identifies Deissmann as the pivotal individual who made it possible to rescue the remains of ancient Ephesus: "Adolf Deissmann dem Wiedererwecker der ephesischen Ausgrabungen als Zeichen herzlichster Verehrung, gewidmet von seinen Mitarbeitern und Freunden Josef Keil, Max Theuer, A. Aziz, Franz Miltner. «10

The photograph of the five-man team was taken before the entrance of the Austrian Archaeological Institute's headquarters in Selçuk. However, the entire collage raises the obvious question, how a German theo-

\footnotetext{
${ }^{4}$ G. A. Deissmann, Study-Travel in New Testament Lands, The Expository Times 25/11, 1914, 486-490. For a modern photographic comparison see photo 29 and colour plate 8, in Wiplinger - Wlach (note 2).

${ }^{5}$ LIMC VIII 1 (1997) 750 s. v. Kybele and LIMC VIII 2 (1997) 508 pl. 19 (H. C. Ackermann - J. R. Giesler): »Kybele wie auf D: dreifiguriger oder auf zwei Figuren verkürzter >ephesischer Typus‘.»

${ }^{6}$ G. A. Deissmann, Das wiedererstehende Ephesos, Die Woche. Moderne Illustrierte Zeitschrift (Berlin) 11, 1927, $297-299 ; 299$.

7 J. Keil, XII. Vorläufiger Bericht über die Ausgrabungen in Ephesos, ÖJh 23, 1926, Beibl. 247-300.

${ }^{8}$ Keil (note 7) 256-257.

${ }^{9}$ G. Sotiriou, ADelt 7, 1922, 177; H. Hörmann, Die Johanneskirche, FiE IV 3 (1951) 254 with pl. $58,5$.

10 »To Adolf Deissmann the reviver of the Ephesus excavations as a token of sincerest admiration. Dedicated by his work-colleagues and friends Josef Keil, Max Theuer, A. Aziz, Franz Miltner.«
} 


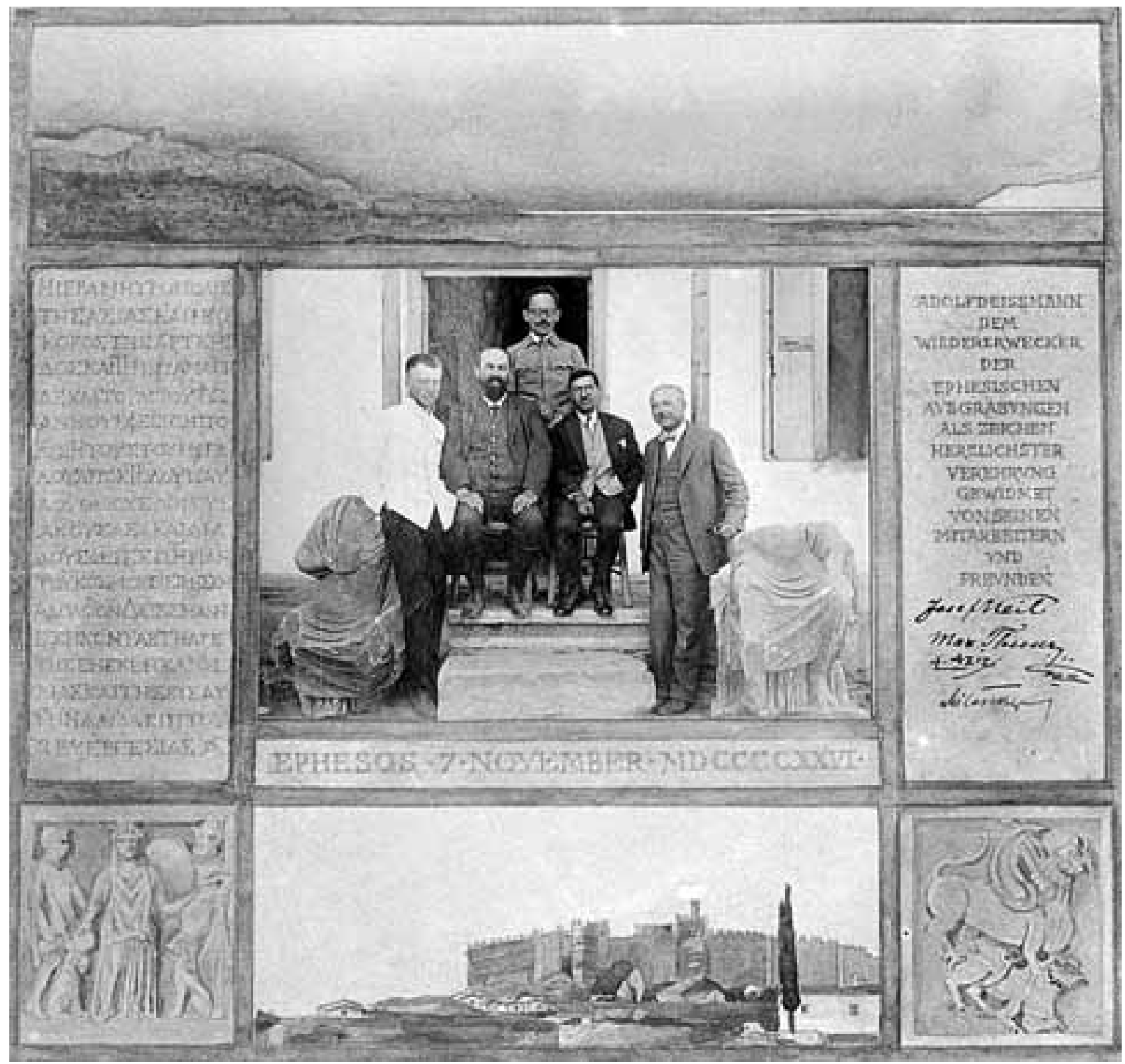

1 Collage diploma in honour of G. A. Deissmann (1926)

logian came to receive such exceptional honours in Ephesus, surrounded by a Bohemian and an Austrian archaeologist, an Austrian expert on ancient architecture and the Turkish commissioner for archaeological excavations. Admittedly, it was Deissmann's sixtieth birthday; but this was hardly reason to describe him as »Wiedererwecker« and for these four men to sign themselves as his »Mitarbeiter«.

Deissmann's archaeological interest had its roots in his two lengthy Orient study-tours of 1906 and 1909, when he was able to visit Ephesus briefly twice, was first introduced to some of the most distinguished archaeological teams at work, and befriended celebrated personalities such as Wilhelm Dörpfeld, Arthur John Evans, Rudolf Heberdey, Maurice Holleaux, Georg Karo, Josef Keil, Theodor Wiegand, Ulrich Wilcken and Georgios Zolotas.

Even though Deissmann had known Wiegand since their 'Gymnasialjahre' in Wiesbaden (1879-1885), the former's letter to his old school friend a month after returning home, shows that they had lost contact: »... es gehört jetzt, im Rückblick auf die ganze Reise zu dem Wertvollsten, daß ich auf dem anatolischen Boden 
die alte Jugendfreundschaft mit Dir habe erneuern dürfen. Nun hoffe ich nur, daß wir recht bald einmal die Freude haben, Dich mit Deiner Gattin hier bei uns zu haben. ... Sonst herrscht große Freude und die erneute Erfahrung, daß ein fester Bund durch längere Trennung nur gefestigt wird. ${ }^{11}$

Ever since Deissmann first set eyes on Ephesus' ruin-scattered landscape, he was deeply struck by its historical significance, especially in respect to early Christianity. Within a year of visiting the site for the second time in 1909 he prepared eight lectures on the Apostle Paul for the University of Uppsala, in which he refers to Ephesus some 28 times and extols the ongoing excavations there ${ }^{12}$.

However, the First World War and the ensuing collapse of the Austro-Hungarian Empire brought an abrupt end to any archaeological work at Ephesus. The only exception occurred in 1921-1922 under Georgios Sotiriou, who was able to excavate parts of the basilica of St. John during the brief Greek occupation of western Asia Minor. Yet despite Deissmann's growing fears regarding Ephesus' bleak post-war fate, it was not until spring 1925 that he was able to initiate a resolute promotional campaign to raise both awareness of its plight and funds to enable the archaeological investigations to be recommenced.

Initially, Deissmann contacted J. Keil with his idea, for he was arguably the world's best living authority on Ephesus, and they had maintained contact over the previous two decades. Furthermore, the ÖAI was the only body licensed by the Turkish authorities to undertake diggings at Ephesus ${ }^{13}$. Deissmann proposed that they draw up a joint plan to recommence work in autumn 1926, for which he himself would raise the necessary financing, while Keil would organise a professional team.

A few months later Keil was employed by the American Society for Archaeological Research in Asia Minor to make a surface survey of Cilicia ${ }^{14}$. It is from there that Keil detoured to make his first brief inspection of Ephesus since 1913, which enabled him to send Deissmann an up-to-date report on its condition.

The site turned out to be in far greater jeopardy than they had thought. Two earthquakes had occurred in western Anatolia during recent years: one in November 1919, the other in November 1924. Until the Turkish government raised the road level between Ephesus and the Kaystros in the mid-1980s, the remains of the ancient city were also subject to annual flooding, detritus, rampant vegetation growth and frequent burning off. But the most pressing problem was the imminent threat of wholesale plundering. During Turkey's struggle for independence the nearby village of Ayasoluk was razed to the ground (1923) and its Greek residents expelled. Turkish Muhajirs proceeded to build a new town on the rubble and renamed it Selçuk; and the steady influx of these immigrants triggered a growing demand for building materials, of which an obvious and convenient source was the stones and marble slabs of Ephesus' exposed ruins.

During the War, and until November 1921, Deissmann wrote and edited the weekly semi-political communiqués »Evangelischer Wochenbrief «, of which (until 1917) an English edition, the »Protestant Weekly Letter «, was sent to carefully selected subscribers chiefly throughout America. One effect of these 'letters' was a widening international circle of prominent friends, such as the founder and first President of Czechoslovakia, Tomás Garrigue Masaryk. Another one of these friends was the Episcopalian Bishop of New York State West, Charles Henry Brent, who was also on the board of trustees for the Laura Spelman Rockefeller Memorial Fund in New York.

Deissmann met Brent for the first time in August 1925 at the Stockholm »Universal Christian Conference on Life and Work «, where they privately discussed the plight of Ephesus. About three months later Brent wrote to Deissmann that he had contacted Dr. Beardsley Ruml, Director of the Rockefeller Fund, and that Ruml had recommended Deissmann should send some details about his salvaging plans to Willard S. Rich-

11 »In looking back at the entire journey, part of what I now value most, is that I was allowed on that Anatolian soil to renew our old schoolboy friendship with you. Now I only hope that we will very soon have the pleasure of entertaining you and your wife here with us ... other than that, there is great happiness and the renewed experience that a strong bond is only strengthened through prolonged separation.«; 4. 7. 1906, DAI NL Wieg., Kiste 2.

12 Published first in Swedish (1910) and revised in German as G. A. Deissmann, Paulus. Eine kultur- und religionsgeschichtliche Studie (1911).

${ }^{13}$ For a recent study on the earlier British excavations, see I. Donkow, The Ephesus excavations 1863-1874, in the light of the Ottoman legislation on antiquities, AnatSt 54, 2004, 109-117.

${ }^{14}$ Investigations resulted in W. M. Calder, MAMA I (1928), E. Herzfeld - S. Guyer, Meriamlik und Korykos. Zwei christliche Ruinenstädte des rauhen Kilikiens, MAMA II (1930) and J. Keil - W. Wilhelm, Denkmäler aus dem rauhen Kilikien, MAMA III (1931). 
ardson, the Fund's Secretary and private spiritual advisor of John Davison Rockefeller Jr., son of the then wealthiest man on earth ${ }^{15}$.

Brent's suggestion to Deissmann is worth noting, because he was clearly motivated by precedent. Richardson had once before been approached to support a comparable archaeological expedition in Anatolia. On 28 December 1922, the American classicist William Hepburn Buckler presented a paper at New Haven to a joint meeting of the American Historical Association and the Archaeological Institute of America, entitled »Historical and archaeological opportunities in the Near East«. In it he shrewdly predicted that as a result of Turkey's political changes, Anatolia would soon present archaeological opportunities where "Americans can do ... work on a scale which European scholars cannot at present afford « ${ }^{16}$. Within months of this speech Buckler had submitted a plan to Richardson for funding of a large-scale systematic archaeological surface survey of the whole of Asia Minor (see above), which Rockefeller's Benevolence Committee agreed with and conditionally funded to one-quarter of the proposed $\operatorname{cost}^{17}$.

When Deissmann first conceived the notion of how he could organize a renewal of archaeological investigations at Ephesus, he was reasonably certain of his fundraising prospects on account of his many foreign connections and, therefore, began to mail specifically targeted promotional material to America, including his own prospectus »Excavations in Ephesus « ${ }^{18}$. To facilitate donations, he also established the »Treuhänderschaft Ephesus-Grabung «, a trust fund into which all contributions were to be channelled and which he chaired until his death ${ }^{19}$. But it was on Brent's explicit suggestion at the Stockholm conference that he now mailed this prospectus to Richardson, along with a confident four-page letter ${ }^{20}$, in which he estimated the cost of one season's expedition at US\$20,000, and an English translation of Keil's booklet ${ }^{21}$. Although Richardson's initial reply was sympathetic, he offered little promise for financial assistance ${ }^{22}$. In actual fact, while Deissmann was waiting for a definitive response, Thomas B. Appleget, the new secretary of Rockefeller's Benevolence Committee, wrote to the secretary of the American Archaeological Society, Harold W. Bell, on another matter, but added that they had received Deissmann's proposal and then surprisingly advised: »Mr. Richardson and I would like the opportunity of conferring with you in regard to the possibility of the work at Ephesus being taken over by the American Society. « $^{23}$ Bell’s answer two days later carefully sidestepped this suggestion by requesting a personal meeting instead, after which the matter was dropped ${ }^{24}$. Another month went by before Appleget sent Deissmann the answer he had hoped for, namely that Rockefeller was willing to contribute US\$10,000, provided Deissmann could raise an equivalent amount elsewhere ${ }^{25}$.

Before this good news arrived, Deissmann had also been lobbying vigorously for support within Germany itself, for although he was unaware of Appleget's radical idea, he did know that since the end of the war Italy was also making strong efforts to claim a stake in Ephesus ${ }^{26}$. Already three weeks before Appleget's offer, three separate German sponsors had promised Deissmann they would provide a total of M. 25,000 (US\$ 6,000), with the similar condition that he would raise a corresponding sum from America. Clearly, diplomacy was paramount if a stalemate were to be avoided.

The Ministry for Internal Affairs as well as the 'Notgemeinschaft für Deutsche Wissenschaft' ${ }^{27}$ had each pledged M. 10,000, and an almost perfunctory further M. 5,000 was to come from the Foreign Office. However, Deissmann was still 40\% below Rockefeller's conditional prerequisite, which is why he now had numerous meetings with various high-ranking political figures during the next six weeks. Among these were the Minister for Science, Arts and Education Carl Heinrich Becker; the Assistant Secretary Richard Donnevert;

\footnotetext{
${ }^{15}$ Letter from Deissmann to Richardson, 16. 12. 1925, Rockefeller Family Archive (F.A.), folder 481.

${ }^{16}$ Rockefeller F. A., folder 480.

${ }_{17}$ Project proposal, 15. 6. 1923, Rockefeller F. A., folder 480.

${ }^{18}$ Rockefeller F. A., folder 481.

19 The other trustees were Gerhard Rodenwaldt, Emil Reisch and Theodor Wiegand.

20 16. 12. 1925, Rockefeller F. A., folder 481.

${ }^{21}$ J. Keil, Ephesos. Ein Führer durch die Ruinen-Stätte und ihre Geschichte (1915).

22 4. 1. 1926, Rockefeller F. A., folder 481. The original of this letter is mistakenly dated 4. 1. 1925.

23 8. 1. 1926, Rockefeller F. A., folder 480.

${ }^{24}$ 10. 1. 1926, Rockefeller F. A., folder 480 .

25 8. 2. 1926, Rockefeller F. A., folder 481.

${ }^{26}$ Letter from Deissmann to F. Schmidt-Ott, 5. 3. 1926, Bundesarchiv Koblenz R 73/10917.

${ }^{27}$ A nationwide body established in 1920 to distribute funds equitably for academic purposes.
} 
the Assistant Secretary and soon to be Permanent Secretary Reinhold Richter; the President of the 'Notgemeinschaft' Friedrich Schmidt-Ott - also a former Minister - and Martin Karl Gerhart Rodenwaldt, the General Secretary of the German Archaeological Institute (DAI). In the end it was the Foreign Office which came to the rescue by trebling their original subscription although, to avoid political speculations in the press, this was to be kept discreetly quiet ${ }^{28}$. This change of heart by the Foreign Office had come about through a handwritten letter from Deissmann to F. Schmidt-Ott - who was in close liaison with the Foreign Office - suggesting that a quiet cooperation between Germany and Austria would benefit their bilateral relations. However, this politically motivated line did not originate from Deissmann himself, but had come directly to him from the Prussian Parliament via Reinhold Richter ${ }^{29}$.

Thus, Deissmann had in a relatively short time single-handedly achieved what seemed impossible for more than a decade, and the archaeological work at Ephesus was now ready to recommence. It would be easy, however, to stigmatise him as a mere fund-raising theologian who made use of his international connections to seek subjective archaeological authentication for the Christian cause. This is precisely what some Germans had feared at the outset of his campaign; but any such allegations could only cast aspersions on the academic integrity of the ÖAI, which is why J. Keil was stung to remark in a private letter: »Im übrigen wundere ich mich, daß man mir immer von auswärts so schreibt, als hätte er nur für die christlichen Monumente von Ephesos Interesse und wollte uns von den antiken abhalten usw. Es ist fast als ob jemand solche Nachrichten, die ja wirklich der Wahrheit ganz zuwider laufen, absichtlich in die Welt setzte. Mir gegenüber hat Deissmann von Anfang an einen ganz anderen Standpunkt eingenommen ... «. ${ }^{30}$

Keil's task of organizing an effective work party had turned out more difficult than expected, and he felt compelled to write to the well-connected Wiegand for advice. In his letter he confided that his greatest misgiving for a successful undertaking was the Institute's lack of archaeologically-experienced architects, since the Ephesus veteran Wilhelm Wilberg - who had taken part in the early campaigns from 1899-1908, 1911 and 1913 - was now too old for this work ${ }^{31}$. Thus far, Max Theuer was plainly not yet in Keil's mind for the position, since more than four months later he writes in another letter to Wiegand that Hans Hörmann, his most recent prospect, was unavailable on account of a possible posting to Bayern ${ }^{32}$. Even though the latter was able to join the team in 1927, eventually Wiegand settled on Theuer for the 1926 season.

Franz Miltner was barely 25 years old, but had already shown himself a promising archaeologist with his local work near Vienna at the amphitheatre of Petronell-Carnuntum. In 1925 he had also accompanied Keil to Cilicia (see above) for inscriptional work. As it turned out, he proved to be an excellent choice, since he became an integral part of every Ephesus campaign until 1931 and again from 1954 until his untimely death in $1959^{33}$.

Ahmet Aziz Oğan (normally referred to as Aziz Bey) was included in the team as a result of negotiations between the Turkish government and the Austrian Chargé d'Affairs August Kral. He was an archaeologist who led the excavations undertaken by the Smyrna Museum, and later became Turkish General Director of Istanbul's Museums; he took part in each Ephesus excavation between 1926 and 1930.

As late as May that year the widespread political uncertainties, particularly with regard to Italy's expansionist Prime Minister Benito Mussolini, had compelled Turkey to call a halt on all archaeological work and travel within western Anatolia; and it appeared that Ephesus was to suffer yet another year's critical delay. However, Kral was able to obtain the Turkish government's acquiescence, by urging that the campaign could go ahead under the aegis of the Smyrna Museum, with Aziz acting as their formal leader, although in practice he worked in complete cooperation with the planned strategy of Keil and Deissmann. Despite the latter's inexperience in archaeology, his role in the 1926 expedition was not peripheral, as he himself explained to

\footnotetext{
${ }^{28}$ Letter from Deissmann to F. Schmidt-Ott, 8. 3. 1927, Bundesarchiv Koblenz, R 73/10917.

${ }^{29}$ Deissmann to F. Schmidt-Ott, 5. 3. 1926.

30 »Besides, I wonder why people keep writing to me from abroad as if his interests were purely fixed on Ephesus' Christian monuments and he intended to keep us from the antique ones, etc. It almost appears as if someone has deliberately sparked such rumours, which really run completely contrary to the truth. As far as I'm concerned, Deissmann has taken an entirely different position right from the beginning ...«. Letter to Th. Wiegand, 12. 5. 1927, DAI, NL Wieg., Kiste 5.

31 26. 12. 1925, DAI, NL Wieg., Kiste 5.

32 J. Keil to Th. Wiegand, 10. 5. 1926, DAI, NL Wieg., Kiste 5.

33 Wiplinger - Wlach (note 2) 184.
} 
the President of the 'Notgemeinschaft': »Ich gehe als Sachverständiger für die altchristlichen Dinge mit und habe einen beträchtlichen Einfluß auf das in diesem Sommer 1926 beginnende Gesamtunternehmen.« ${ }^{34}$ His claim is also born out by a letter from the Director of the ÖAI, Emil Reisch, to Wiegand, where Reisch confirms that Keil will lead the expedition, but that »... [wir] innerhalb des Rahmens dieses österreichischen Unternehmens ... uns selbstverständlich gerne bereit erklärt [haben], Herrn Prof. Deissmann einen von ihm noch zu bestimmenden Anteil an den gestellten Aufgaben zu selbstständiger Bearbeitung zu überlassen. $\ll^{35}$

The first fully organized Austrian excavation team to return to Ephesus since 1913 arrived there at the beginning of September 1926. Deissmann himself was unable to leave Berlin for another six weeks; but once he reached Ephesus and witnessed the fully operating activities on the site he had so passionately campaigned for, he wrote to Wiegand: »Dass es nach vielen Enttäuschungen schließlich doch gelungen ist, diese Thür [i. e. to Ephesus] wieder offen zu machen, ist eine der größten Freuden meines Lebens ${ }^{36}$. This was far more than prideful or romantic pleasure in what he had achieved, for shortly afterwards he wrote in another letter to an English friend: »I began this new period of my life in a new inspiration [sic], being here for many weeks and participating in the new excavation work of the Vienna Institute ... « ${ }^{37}$. Deissmann clearly envisaged for himself a future role in relation to Ephesus that would be more akin to scientific archaeology than academic theology.

His claim of physical participation in these excavations was no overstatement. His lack of formal archaeological training was compensated by his pioneering philological work in the language of early Christianity, and his innovative creation of New Testament philology as a new sub-discipline of Biblical studies ${ }^{38}$. His wide experience with published inscriptions and papyri played an important role in all matters relating to Ephesus' Christian period.

Deissmann commenced his work at Ephesus by comparing Sotiriou's four-year-old photographs of the St. John's Basilica with the ransacked state of the partially excavated edifice. He became so appalled at the damage that he reported: »... the inhabitants of the Turkish village Seltchouk [sic] ... have plundered and are still plundering these venerable ruins in a horrible measure when they are erecting their houses and stables. ॥ $^{39}$ In an earlier letter to the 'Notgemeinschaft' he had pointed out that almost all of the marble flooring and a large section of a tiled wall had been removed, while much of the remaining marble architecture was toppled over and smashed ${ }^{40}$. Upon Sotiriou's forced termination of his work in 1922 (see above), he had to leave more than half of the ruined church still buried under five to six metres of rubble, but was able to store a large amount of its smaller sculptures and architectural fragments in an unused Mosque in neighbouring Ayasoluk. Unfortunately, this building was soon taken over by Muhajirs and, with the constant comings and goings of different occupants, Sotiriou's collection (except for a few heavy blocks) all but disappeared. However, within two weeks of Deissmann's arrival he had re-discovered most of the missing items - fitted into various stone walls in the neighbourhood of the old Mosque - and with Aziz' energetic intervention in conjunction with the local authorities was able to recover several wagonloads ${ }^{41}$.

Deissmann remained an integral participant in all four campaigns until 1929, and was primarily engaged with work at the St. John's Basilica, the Seven Sleepers' cemetery and the Vedius Gymnasium. That Keil consulted him about the significance of some of the epigraphic finds is clear from the way he credits Deiss-

\footnotetext{
34 »I am taking part as specialist in early Christian matters, but have considerable influence on the entire undertaking, which will commence in summer 1926.«; 5. 3. 1926, Bundesarchiv Koblenz, R 73/10917.

35 »... within the scope of this Austrian undertaking, we are, of course, gladly prepared to leave for Prof. Deissmann a part of the projected tasks - yet to be determined by him - for his own research.«; 20. 8. 1925, Bundesarchiv Koblenz, R 73/10917.

${ }^{36}$ »It is one of the greatest delights of my life that after many disappointments we have at long last succeeded in reopening this door« (i.e. to Ephesus); 23. 10. 1926, DAI, NL Wieg., Kiste 2.

${ }^{37}$ H. I. Bell, 14. 11. 1926, Lambeth Palace, Bell Papers, vol. 18 (i).

${ }^{38}$ See A. Gerber, Gustav Adolf Deißmann, die Heidelberger Papyri und ein Durchbruch in griechischer Philologie (forthcoming in Proceedings of the $24^{\text {th }}$ International Congress of Papyrology, Helsinki, 2004).

${ }^{39}$ Letter to Appleget, 21. 2. 1927, Rockefeller F. A., folder 481.

40 7. 2. 1927, Bundesarchiv Koblenz, R 73/10917.

${ }^{41}$ From Deissmann's 1926 report to the Laura Spelman Rockefeller Memorial Fund, Rockefeller F. A., folder 481.
} 
mann in his reports ${ }^{42}$. However, active fieldwork became impossible for him after 1930, due to his heavy workload as Rektor of the Berlin University. Nevertheless, he continued his fundraising and promotional efforts for Ephesus to the end of his life. Although badly falling exchange rates forced the work to be brought to a premature (but planned) conclusion with the 1935 season, one of the very last letters Deissmann ever received came from Karl Griewank of the 'Notgemeinschaft' - it was written two days before Deissmann's death and concerns funding for Ephesus ${ }^{43}$.

The laudatory diploma Deissmann received in 1926 had asserted his »ceaseless benefaction« towards Ephesus; yet this unique role can only be appreciated by modern scholarship if it first restores to Deissmann the recognition he deserves for his part in the revival of this historically significant site.

PhD cand. Albrecht Gerber

University of New England, School of Classics, History and Religion, Armidale, NSW, 2351, Australia

References of figures: Fig. 1: ÖAI Vienna.

42 J. Keil, XIII. Vorläufiger Bericht über die Ausgrabungen in Ephesos, ÖJh 24, 1929, Beibl. 35 note 20; idem, XV. Vorläufiger Bericht über die Ausgrabungen in Ephesos, ÖJh 26, 1930, Beibl. 56; see H. Wankel, Inschriften griechischer Städte aus Kleinasien 11, 1 (1979) = Inschriften von Ephesos Ia, 20 pl. 20.

43 3. 4. 1937, Bundesarchiv Koblenz, R 73/10917. 